\title{
Methionine Synthase Reductase
}

National Cancer Institute

\section{Source}

National Cancer Institute. Methionine Synthase Reductase. NCI Thesaurus. Code C105128.

Methionine synthase reductase ( $725 \mathrm{aa}, \sim 80 \mathrm{kDa}$ ) is encoded by the human MT RR gene.

This protein plays a role in both methionine biosynthesis and B vitamin metabolism. 